\title{
KAJIAN KARAKTER SENSORIS DAN EKONOMI PADA KERUPUK SAYUR
}

\author{
SENSORY CHARACTERISTICS AND ECONOMY EVALUATION OF \\ VEGETABLE CRACKERS
}

\author{
Kawiji $^{1}$ \\ ${ }^{1)}$ Staf Pengajar Jurusan Teknologi Hasil Pertanian,Fakultas Pertanian,Universitas Sebelas Maret, Surakarta
}

\begin{abstract}
Vegetable crackers are kind of crackers that are made of carrot, spinach and sweet corn in order that this product is rich in nutrients and vitamins. The objective of this research was to formulate crackers as new product which are carbohydrate and vegetable basis that have increased value of vitamin, protein and iron compound content. Vegetable crackers as new product that was created practically can increase vegetable product diversification to become product that is ready to consume.

The making of vegetable crackers were comprised of several steps. There were sortation, blanching, spices size reducing, dough making, steaming, cooling, making shape of crackres, drying, frying and packaging. Based on the comparison of t-test and t-table value was known that color, visibility, aroma, hot spicy and salty from two kinds of crackers were similar. Whereas, texture and overall were different. Based on ranking and scoring test, vegetable crackers with sweet corn addition was prefered by consumer to the others. Therefore, vegetable crackers with sweet corn addition as product that will be produced and be analyzed based on economical analysis.

Production cost that was used in vegetable crackers making was $R p R p 296.676,1$ per day and $R p$ 55.006,6 as net profit that was obtained per day with vegetable crackers production capacity everyday was 17,6 kg with Rp 2.000 per 100 grams (1 pack). Based on visibility study was obtained Break Even Point (BEP) production 148,3 packs, meaning that in production level there were 148 packs will produce break event point. Return of Invesment (ROI) value before tax was 18,65\% and after tax was 18,54\%.
\end{abstract}

Keywords: economical evaluation, sensory characteristic, vegetable crackers

\begin{abstract}
Abstrak
Kerupuk sayur adalah kerupuk dengan bahan-bahan wortel, bayam dan jagung manis, dengan demikian kerupuk sayur ini merupakan kerupuk yang mengandung berbagai zat gizi dan vitamin. Kandungan sayuran inilah yang menjadikan kerupuk sayur ini sebagai makanan camilan yang bermanfaat bagi kesehatan. Tujuan penelitian ini memunculkan produk olahan baru berbasis karbohidrat dan sayuran berbentuk kerupuk yang memiliki nilai tambah vitamin, protein dan kandungan zat besi. Produk baru sebagai kerupuk sayur yang dirancang praktis ini, diharapkan mampu meningkatkan diversifikasi produk sayuran sehingga menjadi produk olahan yang siap konsumsi.

Pembuatan kerupuk sayur terdiri dari beberapa tahap, yaitu sortasi, penimbangan, pemblanchingan, penghalusan bumbu-bumbu, pembuatan adonan, pengukusan, pendinginan, pencetakan, pengeringan, penggorengan dan pengemasan. Dari perbandingan t hitung dan t tabel diketahui bahwa warna, kenampakan, aroma, rasa pedas dan rasa asin dari kedua jenis kerupuk adalah sama, sedangkan tekstur dan keseluruhannya berbeda. Dari uji ranking dan skoring kerupuk sayur dengan jagung manis lebih disukai sehingga kerupuk sayur yang akan diproduksi adalah kerupuk sayur dengan penambahan jagung manis dan selanjutnya jenis kerupuk ini yang dianalisis ekonominya.

Biaya produksi yang digunakan dalam pembuatan kerupuk sayur sebesar Rp Rp 296.676,1 per hari dan laba bersih yang diperoleh sebesar Rp 55.006,6 per hari dengan kapasitas produksi kerupuk sayur setiap hari adalah 17,6 kg dengan harga Rp 2.000 per 100 gram (1 bungkus). Berdasarkan perhitungan kelayaan usaha diperoleh Break Even Point (BEP) produksi sebesar 148,3 bungkus (148 bungkus), yang artinya pada tingkat produksi sebanyak 148 bungkus akan menghasilkan titik impas. Besarnya Return of Invesment (ROI) sebelum pajak yaitu 18,65 \% dan ROI sesudah pajak yaitu 18,54\%.
\end{abstract}

Kata Kunci: karakter sensoris, kerupuk sayur, evaluasi ekonomi

\section{PENDAHULUAN}

Kerupuk merupakan makanan yang sudah tidak asing lagi bagi masyarakat Indonesia. Kerupuk adalah jenis makanan kering yang mengandung pati cukup tinggi, dibuat dari bahan dasar tepung tapioka.
Perbedaan bahan pembantu rempah-rempah yang ditambahkan menghasilkan jenis kerupuk yang berbeda. Sifat-sifat yang mencerminkan mutu kerupuk adalah tekstur, cita rasa, dan kenampakan.

Pada dasarnya bahan baku kerupuk adalah tepung berpati seperti tepung tapioka, 
tepung jagung, tepung kentang, dan tepung beras telah banyak digunakan sebagai bahan pembuatan kerupuk. Kerupuk dapat diperkaya dengan protein misalnya kerupuk ikan. Sumber protein selain diperoleh dari hewan, dapat pula dari bahan nabati.

Di Indonesia, berbagai macam sayuran telah banyak dikenal masyarakat. Secara ekonomis, sayuran dapat digunakan untuk berbagai kepentingan dalam bentuk sayuran segar maupun olahan sayuran. Kerupuk dan sayuran merupakan makanan yang sudah tidak asing lagi bagi masyarakat Indonesia. Berbagai macam olahan kerupuk dan sayur banyak disajikan di meja makan.

Produksi sayuran Indonesia berlimpah namun belum banyak produk sayuran yang diolah menjadi produk siap konsumsi. Oleh karena itu perlu dilakukan upaya-upaya pemanfaatan tanaman sayuran sebagai produk siap konsumsi yang mempunyai nilai gizi dan nilai ekonomis lebih tinggi dibanding sayuran segar.

Praktek produksi ini bertujuan untuk mengenali bidang pekerjaan dan meningkatkan ketrampilan yang sesuai kebutuhan pasar kerja, serta mampu berwirausaha dibidang keahliannya. Maka dalam praktek produksi ini dimaksudkan untuk mengolah sayuran menjadi produk olahan siap konsumsi, yaitu kerupuk sayur. Dalam hal ini kerupuk sayur mempunyai nilai tambah karena pada sayuran yang digunakan, yaitu bayam, wortel dan jagung banyak terdapat vitamin dan zat besi yang sangat dibutuhkan tubuh. Dimana kita ketahui bahwa bayam mengandung kalsium, vitamin A dan zat besi. Sedangkan wortel banyak mengandung vitamin $\mathrm{A}, \mathrm{B}$ dan $\mathrm{C}$. Jagung banyak mengandung karbohidrat dan protein. Selain itu kerupuk sayur dalam pembuatannya tidak menggunakan bahan pengawet dan pewarna buatan serta bahan pengembang yang membahayakan kesehatan.

Tujuan penelitian ini memunculkan produk olahan baru berbasis karbohidrat dan sayuran berbentuk kerupuk yang memiliki nilai tambah vitamin, protein dan kandungan zat besi. Produk baru sebagai krupuk sayur yang dirancang praktis ini, diharapkan mampu meningkatkan diversifikasi produk sayuran sehingga menjadi produk olahan yang siap konsumsi.

\section{METODOLOGI}

Kegiatan penelitian kerupuk dengan tambahan sayur dan dikenalkan sebagai krupuk sayur telah dilaksanakan pada tanggal Mei sampai dengan Juli 2006, bertempat di Laboratorium Rekayasa Proses Pengolahan Pangan dan Hasil Pertanian Teknologi, Jurusan Teknologi Hasil Pertanian, Fakultas Pertanian, Universitas Sebelas Maret Surakarta. Penelitian lanjutan ini dibantu salah satu staf Jurusan Teknologi Pertanian (Andriyani) dan juga beberapa mahasiswa (Ayun D.R, Ely T., Warsiti)

Bahan yang digunakan adalah bayam, wortel, jagung manis, tepung tapioka, cabai merah besar, garam, bawang putih dan penyedap rasa. Bahan-bahan diperoleh dari pasar disekitar Surakarta. Peralatan yang digunakan diusahakan yang mudah dijumpai di pasaran. Peralatan yang diperlukan untuk percobaan ini adalah blender, timbangan, roller, cetakan, pisau stainless steel, kompor, penggorengan, sendok, panci dan perekat kemasan (sealer).

Pembuatan kerupuk sayur diawali dengan mensortasi bahan-bahan yang akan digunakan (wortel, bayam, jagung, bawang putih, cabai), kemudian menimbang bahanbahan sesuai dengan komposisi percobaan (lihat tabel 1). Blancing wortel dan bayam perlu dilakukan selama 10 menit.

Tabel 1. Komposisi Bahan Kerupuk Sayur

\begin{tabular}{|c|l|c|c|}
\hline No & \multicolumn{1}{|c|}{ Bahan } & A & B \\
\hline 1 & Daun Bayam & $2 \mathrm{~kg}$ & $2 \mathrm{~kg}$ \\
\hline 2 & Wortel & $2 \mathrm{~kg}$ & $2 \mathrm{~kg}$ \\
\hline 3 & Jagung manis (pipilan) & $4 \mathrm{~kg}$ & - \\
\hline 4 & Tepungjagung (maizena) & - & $4 \mathrm{~kg}$ \\
\hline 5 & Tepung tapioka & $8 \mathrm{~kg}$ & $8 \mathrm{~kg}$ \\
\hline 6 & Cabai & $1,6 \mathrm{~kg}$ & $1,6 \mathrm{~kg}$ \\
\hline 7 & Garam & $0,2 \mathrm{~kg}$ & $0,2 \mathrm{~kg}$ \\
\hline 8 & Bawang putih & $0,8 \mathrm{~kg}$ & $0,8 \mathrm{~kg}$ \\
\hline 10 & Air & - & 6,4 liter \\
\hline
\end{tabular}

Kerupuk sayur formula A menggunakan jagung yang diblanching selama \pm 20 menit, sedangkan kerupuk sayur dengan formula B menggunakan tepung jagung (maizena) dengan penambahan air untuk melarutkan tepung jagung. Selanjutnya menghaluskan bumbu-bumbu (cabai, bawang putih, dan garam) dan sayuran yang telah diblancing. 
Kemudian diteruskan dengan mencampur tepung tapioka, dengan bumbu dan sayuran yang telah dihaluskan serta penyedap rasa sampai adonan menjadi kalis. Adonan yang telah jadi dimasukkan dalam plastik lalu dikukus 30 menit, kemudian adonan yang telah dikukus didinginkan selama 15 menit. Pencetakan krupuk sayur ini dimulai dengan mengerol adonan sampai terbentuk lembaran-lembaran yang halus, kemudian dilanjutkan dengan mencetak adonan sesuai dengan selera. Proses seterusnya adalah mengeringkan adonan yang telah dicetak di bawah sinar matahari atau dengan alat pengering. langkah terakir sebelum dikemas adalah menggoreng kerupuk yang sudah kering, lalu dilakukan pengemasan dan dipasarkan.

Penelitian ini menggunakan dua analisis yaitu analisis sensoris dan analisis Ekonomi. Analisis sensoris untuk mengetahui sifat sensoris dari kerupuk sayur. Analisis ini dilakukan dengan menggunakan scoring test dan rangking test. Parameter yang diukur adalah warna, kenampakan, aroma, rasa, tekstur dan keseluruhan. Panelis yang digunakan dalam pengujian adalah 25 orang, yang berasal dari lingkungan kampus. Analisis Ekonomi digunakan untuk mengetahui kelayakan usaha pembuatan kerupuk sayur, meliputi Fixed Cost, Variable Cost, BEP (Break Even Point), dan ROI (Return of Invesment).

\section{HASIL DAN PEMBAHASAN}

\section{Kerupuk Sayur}

Sayuran sangat bermanfaat bagi
kesehatan tubuh, karena sayuran mengandung berbagai zat gizi dan vitamin. Kerupuk sayur terbuat dari sayuran segar, yaitu bayam, wortel dan jagung manis. Karena sayuran inilah, maka kerupuk sayur dijadikan makanan cemilan yang bermanfaat bagi kesehatan. Menurut Bandini. Y dan Nurudin Azis (1998) ditinjau dari kandungan gizinya, bayam merupakan jenis sayuran hijau yang banyak manfaatnya bagi kesehatan dan pertumbuhan badan, terutama bagi anak-anak dan para ibu yang sedang hamil.
Wortel banyak mengandung karoten A (provitamin A) yang sangat tinggi. Selain sumber dari vitamin A, umbi wortel juga mengandung vitamin $\mathrm{B}$, dan $\mathrm{C}$. Sedangkan jagung banyak mengandung karbohidrat sebagai sumber energi bagi tubuh. Selain itu bumbu-bumbu yang digunakan seperti cabai yang banyak mengandung vitamin $\mathrm{C}$, garam bermanfaat memberikan rasa asin, untuk mengawetkan makanan dan mengandung yodium untuk mencegah penyakit gondok, sedangkan bawang putih mengandung kalori dan memiliki kandungan gizi seperti vitamin $\mathrm{C}$, mineral dan vitamin $\mathrm{B}$.

\section{Proses Pembuatan Kerupuk Sayur}

Proses pembuatan kerupuk sayur diawali dengan sortasi sayuran yang akan digunakan, yaitu wortel, bayam dan jagung. Wortel yang digunakan adalah wortel segar, tidak terlalu tua, tidak ada kotoran yang menempel dan tidak ada cacat pada wortel. Sortasi bayam dilakukan dengan memilih bayam yang masih segar, dihilangkan batang dan kotoran yang terikut. Sedangkan jagung yang digunakan yaitu jagung manis yang masih muda, segar dan tidak cacat. Proses selanjutnya adalah penimbangan, penimbangan dilakukan sesuai formulasi supaya dihasilkan kerupuk sesuai dengan yang dikehendaki.

Sayuran yang telah disortasi kemudian diblanching selama \pm 10 menit. Menurut Winarno, et.al., (1980) pemblanchingan dilakukan untuk mempertahankan warna dan menginaktifkan enzim-enzim didalam bahan pangan, diantaranya enzim katalase dan peroksidase yang merupakan enzim yang paling tahan panas didalam sayuran. Blanching juga dapat mematikan beberapa mikroba. Blanching biasanya dilakukan pada suhu $82-93^{\circ} \mathrm{C}$. Setelah itu sayuran yang telah diblanching tersebut dihaluskan sampai menjadi bubur.

Proses selanjutnya adalah pencampuran yang dilakukan dengan mencampur sayuran halus, tepung tapioka, bumbu-bumbu yang telah dihaluskan (bawang putih, cabai, garam) dan penyedap rasa secukupnya. Pencampuran dilakukan sampai adonan homogen dan kalis. Pencampuran yang kurang homogen menyebabkan penurunan 
proses gelatinisasi sehingga kerupuk yang dihasilkan kurang mengembang. Adonan tersebut lalu dikukus selama \pm 30 menit. Lama pengukusan bervariasi tergantung pada jenis bahan. Pengukusan menyebabkan perubahan pada sifat fisik adonan dengan terbentuknya gel yang lebih padat dan elastis. Pengukusan yang terlalu lama menyebabkan adonan menjadi berwarna gelap, sedangkan pengukusan yang kurang menyebabkan adonan menjadi sulit dirol.

Bahan yang telah keluar dari proses pengukusan harus segera didinginkan. Pendinginan ini dimaksudkan agar tidak terjadi pemanasan berlebih pada bahan. Pada proses pembuatan kerupuk sayur, pendinginan ini dimaksudkan untuk memadatkan adonan sehingga mudah dirol dan dicetak.

Adonan yang sudah dingin kemudian dirol. Proses pengerolan bertujuan untuk mendapatkan lembaran adonan yang halus sehingga mempermudah proses pencetakan dan pengeringan. Yang perlu diperhatikan dalam proses pengerolan adalah keseragaman ukuran, ketebatan dan kehalusan sehingga akan menjamin kualitas. Pengerolan dilakukan sampai didapatkan lembaran yang halus dan tidak retak. Setelah itu dilakukan proses pencetakan. Proses pencetakan dilakukan untuk menyeragamkan bentuk dan ukuran sesuai dengan yang diinginkan. Setelah didapatkan bentuk dan ukuran yang seragam lalu dilakukan pengeringan.

Pengeringan dapat dilakukan dengan penjemuran di bawah sinar matahari atau dengan alat pengering. Bahan yang dikeringkan dibawah sinar matahari sebaiknya ditebarkan secara merata sehingga tidak ada penumpukan agar terjadi pengeringan yang seragam. Pengeringan dilakukan sampai kerupuk benar-benar kering, sehingga jamur tidak akan mudah tumbuh pada kerupuk. Setelah kerupuk benar-benar kering kemudian digoreng untuk mencegah terjadinya penyerapan uap air pada kerupuk.

Setelah kerupuk kering secepatnya dilakukan pengemasan, karena dapat menyebabkan kerenyahan kerupuk berkurang. Tujuan pengemasan adalah untuk melindungi produk dari pengaruh luar, sebagai sarana promosi, memudahkan transportasi dan memudahkan penggunaan. Pengemasan dapat dilakukan dengan plastik atau toples. Diagram alir proses pembuatan kerupuk sayur dapat dilihat pada gambar 1 .

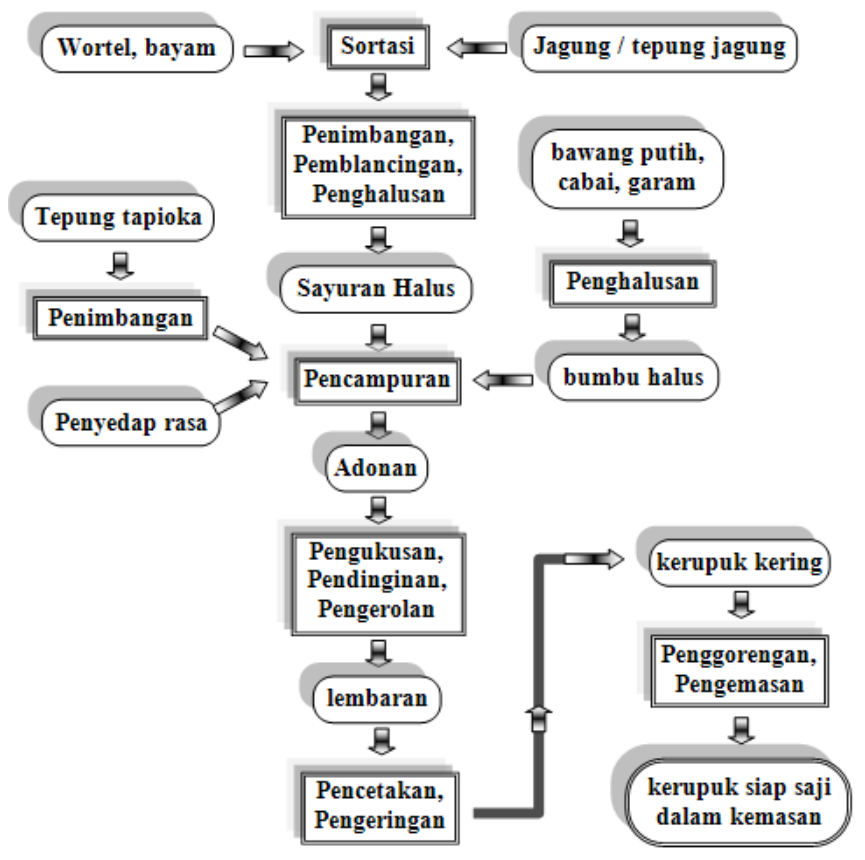

Gambar 1. Diagram Alir Proses Pembuatan Kerupuk Sayur

\section{Rangking Test dan Scoring Test}

Untuk mengetahui warna, kenampakan, aroma, rasa pedas, rasa asin, tekstur dan keseluruhan yang lebih baik dari kerupuk sayur dengan jagung manis (komposisi A) dan kerupuk sayur dengan tepung jagung (komposisi B) maka dilakukan uji skoring. Hasil uji skoring dapat dilihat pada tabel 2.

Dari uji skoring yang telah dilakukan digunakan analisa secara statistik dengan metode T-test menggunakan tabel group statistik dapat dilihat untuk kenampakan kerupuk sayur dengan jagung manis rata-rata penilaian panelis sebesar 2,83, untuk kenampakan kerupuk sayur dengan tepung jagung rata-rata penilaian panelis 2,53, berarti kenampakan kerupuk sayur samasama menarik tetapi kerupuk dengan jagung manis lebih menarik dibandingkan kenampakan kerupuk sayur dengan tepung jagung. Sedangkan warna kerupuk sayur dengan jagung manis dan kerupuk sayur dengan tepung jagung rata-rata penilaian panelis sebesar 2,40, berarti warna kerupuk sayur sama-sama kurang cerah. Aroma kerupuk sayur dengan jagung manis rata-rata penilaian panelis sebesar 2,47 , untuk aroma 
Tabel 2 : Hasil Scoring Test Kerupuk Sayur

\begin{tabular}{|c|c|c|c|c|c|c|c|}
\hline \multirow{2}{*}{ Komposisi } & \multicolumn{6}{|c|}{ Parameter } \\
\cline { 5 - 7 } & \multirow{2}{*}{ Wama } & \multirow{2}{*}{ Kenampakan } & Aroma & \multicolumn{2}{|c|}{ Rasa } & \multirow{2}{*}{ Tekstur } & Keseluruhan \\
\cline { 5 - 8 } & & 2,87 & 1,73 & 2,13 & 2,86 & 1,47 & 3,2 \\
\hline A & 2,4 & 2,53 & 2,67 & 2,4 & 2,47 & 2,27 & 2,47 \\
\hline B & 2,4 & &
\end{tabular}

Keterangan :

\begin{tabular}{|c|c|c|c|c|c|c|c|}
\hline \multirow{2}{*}{$\begin{array}{c}\text { Kisaran } \\
\text { nilai }\end{array}$} & \multirow{2}{*}{ Wama } & \multirow{2}{*}{$\begin{array}{l}\text { Kenam- } \\
\text { pakan }\end{array}$} & \multirow{2}{*}{ Aroma } & \multicolumn{2}{|c|}{ Rasa } & \multirow{2}{*}{ Tekstur } & \multirow{2}{*}{$\begin{array}{l}\text { Keselu- } \\
\text { ruhan }\end{array}$} \\
\hline & & & & $\begin{array}{l}\text { Pedas } \\
\end{array}$ & Asin & & \\
\hline 5 & $\begin{array}{l}\text { Sangat } \\
\text { cerah }\end{array}$ & $\begin{array}{c}\text { Sangat } \\
\text { menarik }\end{array}$ & $\begin{array}{l}\text { Sangat } \\
\text { harum }\end{array}$ & $\begin{array}{l}\text { Sangat } \\
\text { pedas }\end{array}$ & $\begin{array}{c}\text { Sangat } \\
\text { asin }\end{array}$ & $\begin{array}{l}\text { Sangat } \\
\text { keras }\end{array}$ & $\begin{array}{c}\text { Sangat } \\
\text { suka }\end{array}$ \\
\hline 4 & $\begin{array}{l}\text { Lebih } \\
\text { cerah }\end{array}$ & $\begin{array}{l}\text { Lebih } \\
\text { menarik }\end{array}$ & $\begin{array}{l}\text { Lebih } \\
\text { harum }\end{array}$ & $\begin{array}{l}\text { Lebih } \\
\text { pedas }\end{array}$ & $\begin{array}{c}\text { Lebih } \\
\text { asin }\end{array}$ & $\begin{array}{l}\text { Lebih } \\
\text { keras }\end{array}$ & $\begin{array}{c}\text { Lebih } \\
\text { suka }\end{array}$ \\
\hline 3 & Cerah & Menarik & Harum & Pedas & Asin & Keras & Suka \\
\hline 2 & $\begin{array}{l}\text { Kurang } \\
\text { cerah }\end{array}$ & $\begin{array}{l}\text { Kurang } \\
\text { menarik }\end{array}$ & $\begin{array}{l}\text { Kurang } \\
\text { harum }\end{array}$ & $\begin{array}{l}\text { Kurang } \\
\text { pedas }\end{array}$ & $\begin{array}{c}\text { Kurang } \\
\text { asin }\end{array}$ & $\begin{array}{c}\text { Kurang } \\
\text { keras }\end{array}$ & $\begin{array}{c}\text { Kurang } \\
\text { suka }\end{array}$ \\
\hline 1 & $\begin{array}{l}\text { Tidak } \\
\text { cerah }\end{array}$ & $\begin{array}{c}\text { Tidak } \\
\text { menarik }\end{array}$ & $\begin{array}{l}\text { Tidak } \\
\text { harum }\end{array}$ & $\begin{array}{l}\text { Tidak } \\
\text { pedas }\end{array}$ & $\begin{array}{c}\text { Tidak } \\
\text { asin }\end{array}$ & $\begin{array}{l}\text { Tidak } \\
\text { keras }\end{array}$ & $\begin{array}{l}\text { Tidak } \\
\text { suka }\end{array}$ \\
\hline
\end{tabular}

Tabel 3. Hasil Uji Rangking Kerupuk Sayur

\begin{tabular}{|c|c|c|c|c|c|c|c|c|c|c|c|c|c|c|c|c|}
\hline \multirow{2}{*}{ Sampel } & \multicolumn{15}{|c|}{ PANELIS } & \multirow[b]{2}{*}{ Jml } \\
\hline & 1 & 2 & 3 & 4 & 5 & 6 & 7 & 8 & 9 & 10 & 11 & 12 & 13 & 14 & 15 & \\
\hline$A$ & 1 & 1 & 1 & 1 & 1 & 1 & 1 & 1 & 1 & 1 & 1 & 1 & 1 & 1 & 1 & 15 \\
\hline$B$ & 2 & 2 & 2 & 2 & 2 & 2 & 2 & 2 & 2 & 2 & 2 & 2 & 2 & 2 & 2 & 30 \\
\hline
\end{tabular}

Keterangan :

1 : sampel lebih disukai

2 : sampel kurang disukai

Kisaran nilai $18-26$

Sampel A (kerupuk sayur dengan jagung manis) $<18=1$ ebih disukai

Sampel B (kerupuk sayur dengan tepung jagung) $>26=$ kurang disukai

kerupuk sayur dengan tepung jagung ratarata penilaian panelis 1,93 , berarti kerupuk sama-sama kurang harum tetapi kerupuk sayur dengan jagung manis lebih harum dibandingkan kerupuk sayur dengan tepung maizena. Rasa pedas kerupuk sayur dengan jagung manis rata-rata penilaian panelis sebesar 2,13, untuk rasa pedas kerupuk sayur dengan tepung jagung rata-rata penilaian panelis 2,40, berarti kerupuk sama-sama kurang pedas tetapi kerupuk sayur dengan tepung jagung lebih pedas dari pada kerupuk dengan jagung manis. Rasa asin kerupuk sayur dengan jagung manis rata-rata penilaian panelis sebesar 2,87, untuk rasa asin kerupuk sayur dengan tepung jagung rata-rata penilaian panelis 2,47 , berarti kerupuk dengan jagung manis lebih asin dibandingkan dengan kerupuk dengan tepung jagung. Tekstur kerupuk sayur dengan jagung manis rata-rata penilaian panelis sebesar 1,47, untuk tekstur kerupuk sayur dengan tepung jagung rata-rata penilaian panelis 3,27, berarti tekstur kerupuk dengan tepung jagung lebih keras dari pada kerupuk dengan jagung manis. Dari keseluruhan penilaian panelis terhadap kerupuk sayur dengan jagung manis didapatkan nilai ratarata penilaian konsumen sebesar 3,20, sedangkan pada kerupuk sayur dengan tepung jagung didapatkan nilai rata-rata sebesar 2,47, berarti dari uji skoring kerupuk sayur dengan jagung manis lebih disukai dari pada kerupuk sayur dengan tepung jagung. Dari uji ranking dan skoring kerupuk sayur dengan jagung manis lebih disukai sehingga kerupuk sayur yang akan diproduksi adalah kerupuk sayur dengan penambahan jagung manis.

Berdasarkan perbandingan $\mathrm{t}$ hitung dan $\mathrm{t}$ tabel dari uji T-test dengan menggunakan independent samples test diperoleh $\mathrm{t}$ hitung 
warna $0,000, \mathrm{t}$ hitung kenampakan $1,043, \mathrm{t}$ hitung aroma 1,623 , $\mathrm{t}$ hitung pedas $-0,928, \mathrm{t}$ hitung asin 1,387, t hitung tekstur $-5,252$ dan $\mathrm{t}$ hitung keseluruhan 3,051. Sedangkan $\mathrm{t}$ tabel dengan tingkat signifikasi $5 \%$, derajat bebas 28 dan jumlah sampel 2 adalah 2,0488. Dari perbandingan tersebut dapat disimpulkan bahwa warna, kenampakan, aroma, rasa pedas dan rasa asin dari kedua jenis kerupuk adalah sama, sedangkan tekstur dan keseluruhannya berbeda (tabel 3).

\section{Hasil Analis Perincian Biaya Produksi}

Analisa perincian biaya ini sangat diperlukan untuk menentukan besarnya biaya produksi, laba, kapasitas produksi dan ROI dalam menjalankan suatu usaha. Sehingga usaha dapat berjalan secara terus menerus dan memberi keuntungan yang sebesarbesarnya.

Berdasarkan analisa biaya produksi dari pembuatan kerupuk sayur dengan bahan dasar sebesar $16 \mathrm{~kg}$ dalam satu kali proses diperoleh 17,6 kg kerupuk matang. Dari hasil analisa tersebut diperoleh biaya tetap sebesar Rp9.591 per hari, biaya tidak tetap sebesar Rp 287.085,1 per hari dan biaya produksi sebesar Rp 296.676,1 per hari. Dari hasil perhitungan diperoleh laba bersih sebesar Rp 55.006,6 per hari dan laba kotor sebesar Rp 55.323,9 per hari. Dari perhitungan analisa kekayaan usaha diperoleh BEP harga sebesar Rp 1.685,6, yang artinya pada tingkat harga $\mathrm{Rp} 1.685,6$ akan menghasilkan titik impas. Untuk memperbesar keuntungan maka produk dijual dengan harga Rp 2000 per 100 gram. BEP produksi sebesar 148,3 bungkus (148 bungkus), yang artinya pada tingkat produksi sebanyak 148 bungkus akan menghasilkan titik impas. Besarnya ROI sebelum pajak yaitu $18,65 \%$ dan ROI sesudah pajak yaitu $18,54 \%$.

\section{KESIMPULAN}

1. Kerupuk Sayur adalah kerupuk dengan bahan-bahan wortel, bayam dan jagung manis, dengan demikian kerupuk sayur ini merupakan kerupuk yang mengandung berbagai zat gizi dan vitamin. Kandungan sayuran inilah yang menjadikan kerupuk sayur ini sebagai makanan camilan yang bermanfaat bagi kesehatan. Pembuatan kerupuk sayur terdiri dari beberapa tahap, yaitu sortasi, penimbangan, pemblanchingan, penghalusan bumbu-bumbu, pembuatan adonan, pengukusan, pendinginan, pencetakan, pengeringan, penggorengan dan pengemasan.

2. Dari perbandingan $t$ hitung dan $t$ tabel diketahui bahwa warna, kenampakan, aroma, rasa pedas dan rasa asin dari kedua jenis kerupuk adalah sama, sedangkan tekstur dan keseluruhannya berbeda. Dari uji ranking dan skoring kerupuk sayur dengan jagung manis lebih disukai sehingga kerupuk sayur yang akan diproduksi adalah kerupuk sayur dengan penambahan jagung manis dan selanjutnya jenis krupuk ini yang dianalisis ekonominya.

3. Biaya produksi yang digunakan dalam pembuatan kerupuk sayur sebesar Rp Rp 296.676,1 per hari dan laba bersih yang diperoleh sebesar Rp 55.006,6 per hari dengan kapasitas produksi kerupuk sayur setiap hari adalah 17,6 kg dengan harga Rp 2000 per 100 gram (1 bungkus).

4. Dari perhitungan kelayaan usaha diperoleh BEP (Break Even Point) produksi sebesar 148,3 bungkus (148 bungkus), yang artinya pada tingkat produksi sebanyak 148 bungkus akan menghasilkan titik impas. Besarnya ROI (Return of Invesment) sebelum pajak yaitu $18,65 \%$ dan ROI sesudah pajak yaitu $18,54 \%$.

\section{DAFTAR PUSTAKA}

AAK, 1993. Teknik Bercocok Tanam Jagung. Kanisius. Yogyakarta.

Bandini, Y dan Nurudin Azis. 1998. Bayam. Penebar Swadaya. Jakarta.

Cahyono, B. 2002. Wortel: Teknik Budidaya dan Analisis Usaha Tani. Kanisius. Yogyakarta.

Gittinger, P. 1986. Analisa Ekonomi Proyekproyek Pertanian. UI-PRESS. Jakarta. 
Hidayat, N dan Suhartini. 2006. Membuat Aneka Kerupuk. Trubus Agrisarana. Surabaya.

Kodoatie, R.1995. Analisis Ekonomi Teknik. Andi Offset. Yogyakarta.

Mardiasmo. 1994. Akuntansi Biaya Penentuan Harga Pokok Produksi. Andi Offset. Yogyakarta.

Maria, S. 2004. Ensiklopedi Makanan Tradisional Indonesia (Sumatera). Kementerian Kebudayaan dan Pariwisata Proyek Pelestarian dan Pengembangan Tradisi dan Kepercayaan.

Myer, N. J. 1982. Analisa Neraca dan Laba Rugi. Aksara Baru. Jakarta.

Oomen, H.A.P.C, Poerwo Soedarmo, Djoeweriah Poorwo Soedarmo,
Surachmat Kusumo. 1992. Si Hijau yang Cantik: Aneka Sayuran Daun Hijau di Indonesia. PT. Gramedia. Jakarta.

Pangestuti, D. 2002. Skripsi: Hubungan Economic Value Added (EVA) dan Return On Investment (ROI) dengan Harga Saham Di Bursa Efek Jakarta. Fakultas Ekonomi.

Santoso, H. B. 1988. Bawang Putih. Kanisius. Yogyakarta.

Tim Penulis PS. 1992. Sweet Corn Baby Corn. Penebar Swadaya. Jakarta.

Winarno dan Titi Sulistyowati Rahayu.

1994. Bahan Tambahan untuk Makanan dan Kontaminan. Pustaka Sinar Harapan. Jakarta. 